УДК 338.33:334.02:364

DOI: https://doi.org/10.32782/2520-2200/2020-4-12

Залуцька X.Я.

кандидат економічних наук, доцент, доцент кафедри економіки підприємства та інвестицій Національного університету «Львівська політехніка»

Zalutska Khrystyna Lviv Polytechnic National University

\begin{abstract}
АНТАГОНІЗМ ОСОБЛИВОСТЕЙ ДИВЕРСИФІКАЦІЇ ТА ІНТЕГРАЦІЇ ЯК ОСНОВНА УМОВА ЗАБЕЗПЕЧЕННЯ ГОМЕОСТАЗУ РОЗВИТКУ ПІДПРИЄМСТВА В УМОВАХ НЕОТЕХНОЛОГІЧНОГО ВІДТВОРЕННЯ
\end{abstract}

\title{
ANTAGONISM OF FEATURES (ADVANTAGES) OF DIVERSIFICATION AND INTEGRATION AS THE MAIN CONDITION FOR ENSURING HOMEOSTASIS OF ENTERPRISE DEVELOPMENT IN THE CONDITIONS OF NEOTECHNOLOGICAL REPRODUCTION
}

В умовах неотехнологічного відтворення оперативне реагування і врахування зміни умов середовищ функціонування підприємств вимагає нових фрорм і напрямків ведення бізнесу. Тому, дослідження та обгрунтування можливості застосування диверсифікаційно-інтеграційного розвитку підприємства у якості визначального напрямку його ефективного фрункціонування в умовах неотехнологічного відтворення $є$ актуальним. Окреслено фрактори впливу на розвиток сучасних підприємств в умовах неотехнологічного відтворення. Визначено заходи, які допоможуть уникнути негативного впливу і максимально врахувати позитивні аспекти виділених факторів впливу. Обгрунтовано переваги диверсифрікаційно - інтеграційного розвитку врахувавши особливості диверсифікації та інтеграції відповідно характеру основних факторів впливу на розвиток сучасних 
підприємств. Доведено, що застосування диверсифрікаційно-інтеграційного розвитку дозволить оптимально-результативно реалізувати заходи зменшення рівня впливу чинників на функціонування підприємств забезпечивши, при цьому, їм ефективний стратегічний розвиток.

Ключові слова: глобальні фактори впливу, локальні фрактори впливу, диверсифікація, інтеграція, диверсифрікаційно-інтеграційний розвиток, заходи зниження впливу, мотиви розвитку.

В условиях неотехнологического воспроизведения оперативное реагирование и учет изменений условий среды функционирования предприятий требует новых форм и направлений ведения бизнеса. Поэтому исследование и обоснование возможности применения диверсификационно-интеграционного развития предприятия в качестве определяющего направления его эффрективного ффункционирования в условиях неотехнологического воспроизведения является актуальным. Определены фракторы влияния на развитие современных предприятий в условиях неотехнологического воспроизведения. Определены меры, которые помогут избежать негативного влияния и максимально учесть положительные аспекты выделенных факторов влияния. Обоснованно преимущество диверсификационно-интеграционного развития с учетом особенности диверсиорикации и интеграции в соответствии с характером основных фракторов влияния на развитие современных предприятий. Доказано, что применение диверсификационно-интеграционного развития позволит оптимально-результативно реализовать меры для уменьшения уровня влияния фракторов на функционирование предприятий, обеспечив при этом им эфффективное стратегическое развитие.

Ключевые слова: глобальные фракторы влияния, локальные фракторы влияния, диверсификация, интеграция, диверсификационно-интеграционное развитие, меры снижения влияния, мотивы развития.

The operating environment of modern enterprises is characterized by dynamism, unpredictability and high technology, which is due to the rapid development of science, the intellectualization of production processes, computerization of society, and the diffusion of innovations in all spheres of life. In the context of neotechnological reproduction, rapid response and consideration of changes in the conditions of business environments require new forms and directions of business, the use of which will not lead to global changes in the company's activities. Therefore, the study and justification of the possibility of applying the diversification and integration development of the enterprise as a determining direction of its effective functioning in the conditions of neotechnological reproduction are relevant. The study was performed using methods: analysis; synthesis; analogies; abstraction; grouping; comparison. The factors of influence on the development of modern enterprises in the conditions of neotechnological reproduction are determined. The selected factors are grouped into two groups: local; global. Local factors, in turn, are divided into those that affect the enterprise at the macro and micro levels. Measures have been identified that will help to avoid negative influences and take into account the positive aspects of the selected influencing factors as much as possible. The selected activities are separately grouped into local and global, which made it possible to clearly outline the requirements for their effective implementation. The advantages of diversification and integration development are substantiated, taking into account the peculiarities of diversification and integration, respectively, the nature of the main factors influencing the development of modern enterprises through the identified motives. It is proved that the use of diversification and integration development will allow us to optimally effectively implement measures to reduce the level of influence of factors on the functioning of enterprises while ensuring their effective strategic development by creating certain long-term competitive advantages.

Key words: global factors of influence, local factors of influence, diversification, integration, diversification and integration development, impact reduction measures, motives for development.

Постановка проблеми. Середовище фрункціонування сучасних підприємств характеризується динамічністю, непередбачуваністю і високою технологічністю, що зумовлено швидким розвитком науки, інтелектуалізацією виробничих процесів, комп'ютеризацією суспільства, дифузію інновацій в усі сорери життєдіяльності. Це, в свою чергу, зумовлює появу нових ідей, потреб, вимог, що вимагає відповідних заходів їх вирішення. Швидкість виникаючих потреб змушує підприємство до оперативного їх задоволення для отримання максимальної вигоди.
Оперативно реагувати на зміни умов середовищ фрунціонування можуть вузькоспеціалізовані підприємства, однак, стійкими до будьяких змін $€$ підприємства, які виготовляють широкий асортимент товарів і надають різноманітний спектр послуг. Перевага таких підприємств полягає в тому, що їх діяльність не залежить від зміни попиту на певний вид товару, тобто, їх функціонування страхується декількома видами продукції, яка реалізовується на різних ринках. Відповідно, зменшення збуту одного виду продукції не призведе до критичних наслідків, оскільки, отримуються доходи і 
від реалізації інших видів продукції чи послуг, що відповідно може виступати у якості страхування чи інвестування нерентабельних на певний момент часу, але привабливих з певних позицій напрямків діяльності у довгостроковій перспективі.

Зовнішня міць таких підприємств послаблюється внутрішньою складністю управління ними, що в результаті, через недостатнє або занадто пильне зосередження уваги на певному напрямку діяльності може призвести до значної втрати привабливої частини ринку (через відмову споживачів від неякісної продукції або продукції із непотрібними властивостями (характеристиками) нарощення яких, звичайно, призвело до її подорожчання).

3 метою оптимально-результативного зосередження уваги на різних напрямках діяльності підприємства варто виділити їх в окремі сорери - бізнес одиниці, які спеціалізуватимуться на певних товарах і послугах. Це дозволить за рахунок виділення притаманних відповідній бізнес одиниці конкурентних переваг і окреслені шляхів їх ефективного досягнення раціонально покращувати якість продукції, оптимізовувати витрати і результативно нарощувати надходження від ії реалізації збільшити кількість споживачів і розширити частку ринку.

Формування конкурентних переваг у даному випадку можливо шляхом виділення спеціалізованих бізнес одиниць у діяльності різнобізнесового підприємства.

Проте, не завжди всі виділені бізнес одиниці мають достатньо можливостей для самостійного подальшого розвитку в швидко змінних і непередбачуваних умовах фрункціонування сучасних підприємств, що відповідно зумовлює необхідність залучення потрібних ресурсів, напрямків діяльності, послуг супровідної діяльності тощо зі сторони.

3 метою оптимізації витрат і раціонального співвідношення між витратами та якістю продукції доцільно залучити потрібних партнерів у такій фрормі, щоб максимально задовольнялися інтереси обох сторін.

Однією із форм можливого залучення потрібних партнерів є інтеграція із ними. Однак, часто для ефективної роботи такого інтеграційного утворення частина діяльності партнера не $€$ привабливою, а її утримання приносить певні витрати, тому доцільно об'єднувати діяльність певних підприємств у межах їх відповідних бізнес одиниць, використовуючи, при цьому, диверсифікаційно-інтеграційний напрямок розвитку. Ефективність такого розвитку залежить від вдалого управління ним, що вимагає максимального врахування можливих факторів впливу на підприємство та оптимально- результативного співвідношення діяльності окремих бізнес одиниць з метою отримання відповідного ефекту, який забезпечить стабільність фрункціонування підприємства в таких динамічно-циклічних умовах розвитку національних економік (умовах неотехнологічного відтворення).

Аналіз останніх досліджень і публікацій. В науковій літературі [1-6] широко описано переваги використання диверсифрікації з метою зменшення впливу чинників зовнішнього середовища на функціонування підприємств різних сорер, галузей діяльності, фрорм власності, розмірів тощо.

Не менш різносторонньо описано переваги інтеграції підприємств для їх ефективного фрункціонування як на вітчизняних, так і зарубіжних ринках [7-9].

Однак, поряд із зазначенням переваг цих форм розвитку розглядаються і труднощі та негативні наслідки їх використання, що може проявлятися у втраті частини ринку через нераціональне виділення бізнес одиниць і брак у деяких із них певних видів ресурсів, значної залежності підприємств від партнерів, значний самостійний розвиток партнерів за рахунок отриманих додаткових можливостей тощо.

Можливість застосування диверсифікації та інтеграції одночасно розглядається М.М. Скоробагатовим [10] та М.Д. Коріньком [11] при виділені основних груп методів диверсифікації: диверсифікація в середині підприємства і диверсифікація через поглинання і злиття. Як бачимо, ці методи здійснення диверсифікації вказують на види диверсифрікації: внутрішню та зовнішню. Внутрішня диверсифікація спонукає суб'єкта господарської діяльності до виробництва нової продукції, урізноманітнення ринків, технологій на основі використання ресурсів, які $€$ в надлишку. Об'єднання підприємств здійснюється в умовах зовнішньої диверсифікації. Вибір підприємства на користь зовнішньої диверсифрікації пояснюється тим, що купівля іншого підприємства відзначається наявністю висококваліфікованого персоналу, налагодженням умов постачання, збуту, технологій, сорормованим іміджем компанії тощо [10].

Тобто, у даному випадку поняття інтеграції розглядається як форма здійснення диверсифрікації, а не ії рівноцінне доповнення. Відповідно, спочатку підприємства інтегруються 3 метою досягнення диверсифікації, а доцільно максимально використати диверсифікаційні можливості підприємства та інтегруватися, відповідно, з тими структурами, чия діяльність для виділених напрямків диверсифікованого підприємства буде привабливою і потрібною та дозволить отримати додатковий ефект, який 
власними силами був би меншим або взагалі відсутнім (неотримувався б).

Диверсифрікаційно-інтеграційний розвиток передбачає інтеграцію як внутрішню на мікроі на макрорівні, так і зовнішню на цих рівнях диверсифікованого підприємства. Внутрішня інтеграція стосується можливості об'єднання елементів певних бізнес процесів, бізнес процесів різних одиниць бізнесу підприємства, бізнес одиниць між собою, зовнішня у свою чергу - інтеграції елементів бізнес процесів різних суб'єктів господарювання (досліджуваного підприємства і певного його стейкхолдера).

Інтегровані підприємства можуть без усяких зусиль здійснювати диверсифікацію, однак важливим в умовах неотехнологічного відтворення є отримання бажаного ефекту, який забезпечить успішне функціонування підприємств за рахунок оптимально-результативного поєднання наявного потенціалу підприємства із привабливими стейкхолдерами через раці- ональні взаємозв'язки між його відповідними бізнес одиницями та їх ключовими складовими.

Відповідно, для того, щоб розширювати свою діяльність необхідно максимально узгодити та інтегрувати складові бізнес процесів підприємства між собою, тобто, максимально використати і прописати можливості внутрішньої інтеграції.

Метою статті $€$ обгрунтування доцільності диверсифікаційно-інтеграційного розвитку підприємства як визначального напрямку його ефрективного функціонування в умовах неотехнологічного відтворення.

Виклад основного матеріалу дослідження. Розвиток сучасних підприємств ускладнюється динамічними і непередбачуваними змінами середовищ їх функціонування. 3 одного боку, чинники зовнішнього середовища, які мають як прямий, так і опосередкований вплив, відповідно, які підприємство не може змінити, однак, має можливість, враховуючи їх особливості здійсню-

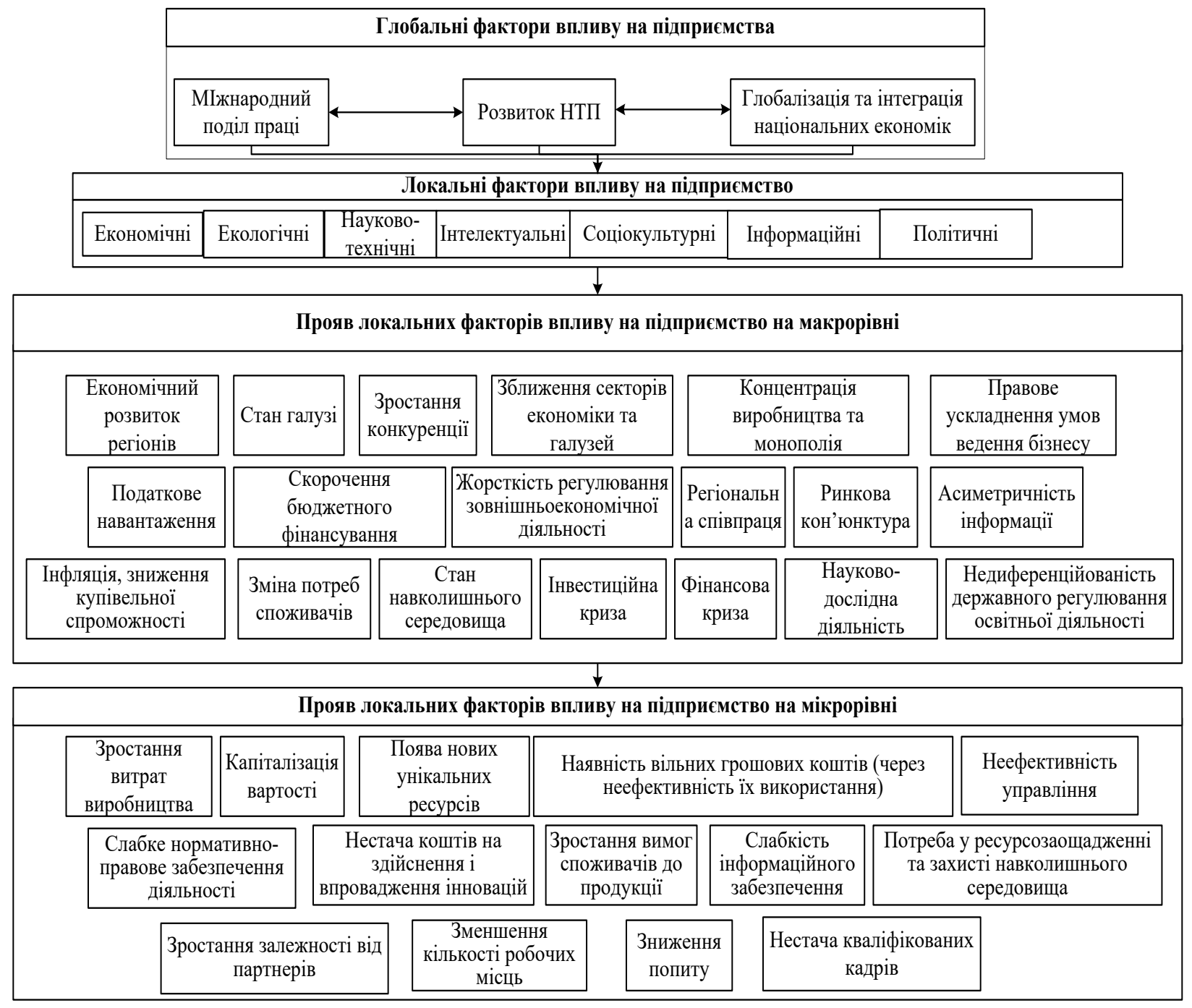

Рис. 1. Систематизація факторів впливу на розвиток підприємств в сучасних умовах їх функціонування 
вати зміни на підприємстві, які забезпечать зниження цього впливу. Наприклад, розвиток НТП впливає на зміну потреб і вподобань споживачів, що вимагає від підприємства пошуку унікальних шляхів їх досягнення для отримання певного виду есректу, який забезпечить підприємству стійку конкурентну перевагу на ринку і ефективність його стратегічного розвитку. 3 іншого боку, здійснення певного виду діяльності та бажання отримати конкретну конкурентну перевагу (прибуток, збільшити частку ринку тощо) змушує підприємство шукати нові можливості покращення якості продукції, розроблення нового виду продукції, шляхів її просування, що відповідно призводить до зміни чинників зовнішнього середовища, оскільки, висуває нові вимоги до конкурентів, породжує потреби споживачів тощо.

Тобто, підприємства функціонують в середовищах із непередбачуваними та динамічно змінними фракторами, які вимагають відповідних змін і від підприємств. Фактори залежно від рівня впливу на підприємство і ступеня його можливого реагування на них доцільно розділити на глобальні і локальні (рис. 1).
Локальні відображають напрямки в яких загальні для світової спільноти (глобальні) чинники можуть впливати на підприємства. В свою чергу, локальні фактори за виділеними напрямками залежно від специфіки країни, її економіки, особливостей окремих галузей можуть впливати на підприємство через певні чинники як на макро-, так і макрорівнях.

Найоперативніше реагувати на зміну середовищ функціонування можуть малі підприємства через їх гнучкість, яка проявляється у швидкому переорієнтуванні на виготовлення нових видів продукції, однак, ця гнучкість $€$ й їхнім недоліком, оскільки, нерентабельність нового виробництва може привести підприємство до банкрутства.

Відповідно, підприємства, які диверсифікують свою діяльність є більш стійкими до зміни умов середовищ їх функціонування, оскільки, втрати отримані при нерентабельному виді діяльності покриваються іншими напрямками діяльності, що дозволяють не зазнати значних збитків і втримати підприємство на ринку чи зайняти новий сегмент ринку, потреби якого задовольнятиме наявна продукція.

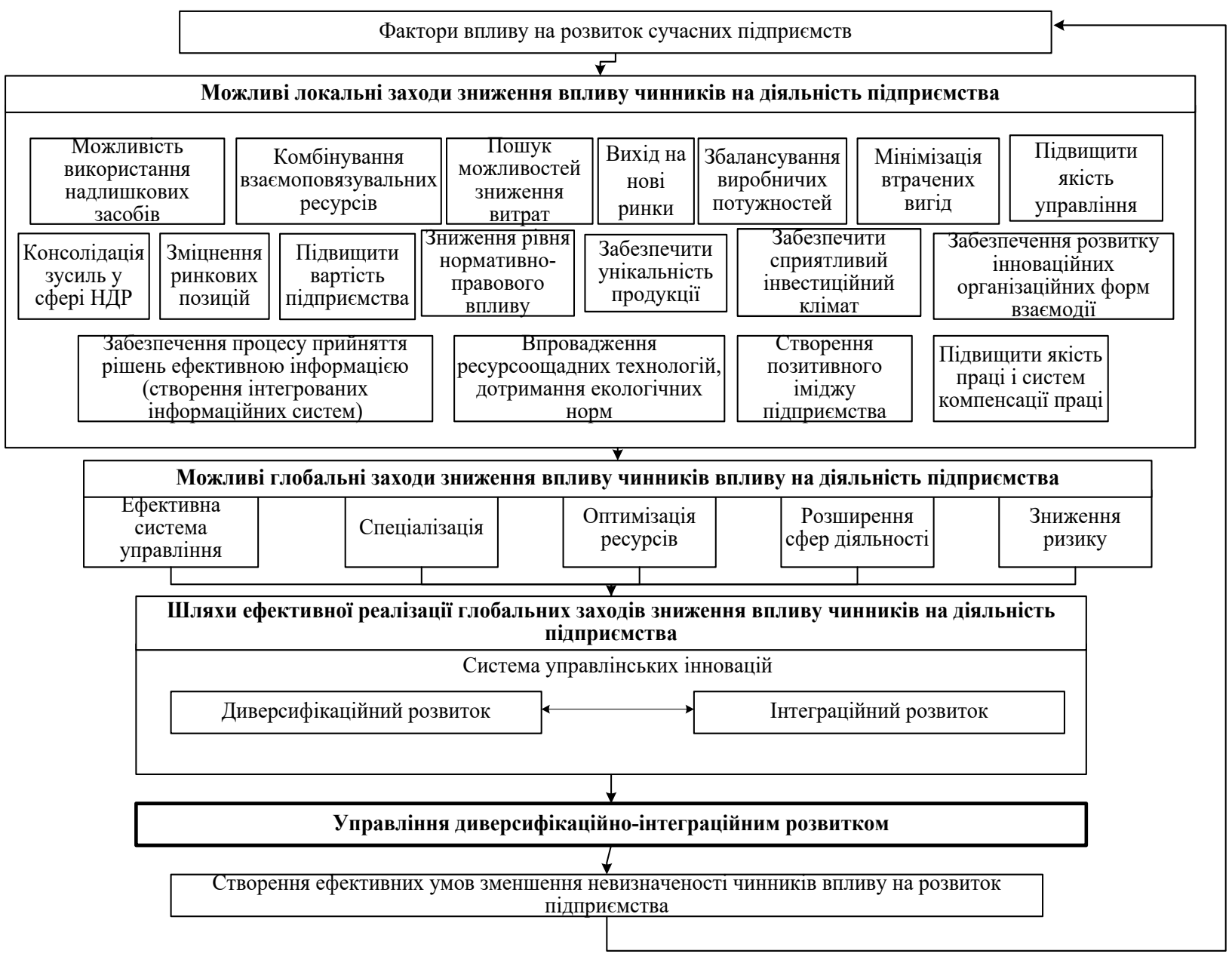

Рис. 2. Антагонізм особливостей (переваг) диверсифрікації та інтеграції як основна умова забезпечення гомеостазу розвитку підприємства в умовах неотехнологічного відтворення 
Функціонування диверсифрікованого підприємства ускладнюється виготовлення значної кількості товарів, що унеможливлює раціональне забезпечення процесу їх виробництва необхідними ресурсами.

Відповідно, виготовлення значного асортименту продукції диверсифікованими підприємствами через складність контролю призводить до:

- високих цін на продукцію і втрати частину ринку, i/або отримання низького рівня прибутку;

- надання продукції великої кількості надлишкових незатребуваних властивостей та характеристик, що також призводить до втрати частини ринку і прибутку;

- втрати можливостей виготовлення унікальної продукції через невчасне реагування на появу нових товарів, які виникають супутньо основному виду діяльності тощо.

Тому, для ефективного функціонування диверсифрікованого підприємства необхідно розділити його на певні спеціалізовані бізнес одиниці, оптимально-результативні взаємозв'язки між якими забезпечать раціональність підприємства і отримання ефекту необхідного для стратегічного розвитку.
На рис. 2 подано, за результатами проведених досліджень, окреслені заходи, які можуть вживати підприємства для уникнення чи зменшення впливу певних чинників на стабільний розвиток підприємства. Зазначені заходи також розділено на локальні і глобальні, що відповідно дозволяє точніше окреслити шляхи їх реалізації.

Для реалізації окремої частини зазначених заходів у диверсифікованого підприємства може не вистачити наявного потенціалу або будуть відсутні можливості його нарощення, що вимагає відповідного їх залучення зі сторони. Для чого диверсифріковані підприємства можуть інтегруватися з іншими привабливими суб'єктами господарювання. При чому, така інтеграція повинна бути вигідною для усіх сторін, підкріплюватися задоволенням цілей об'єднуваних структур і підсилюватися певними мотиваційними заходами.

Переваги диверсифрікації та інтеграції як основних форм пристосування діяльності сучасних підприємств до зміни умов їх функціонування подано на рис. 3.3 рис. 3 видно, що $\mathrm{i}$ диверсифрікація, і інтеграція мають суттєві недоліки, які створюють труднощі для ефективного

\begin{tabular}{|c|c|c|c|}
\hline \multicolumn{4}{|c|}{ Особливості використання } \\
\hline & & \multirow{2}{*}{\multicolumn{2}{|c|}{$\frac{\downarrow}{\text { Інтеграції }}$}} \\
\hline \multicolumn{2}{|c|}{ Диверсифікації } & & \\
\hline $\begin{array}{c}\text { Переваги: } \\
\text { - підвищує рівень зайнятості } \\
\text { населення; } \\
\text { - забезпечує зниження } \\
\text { сезонності виробництва; } \\
\text { - покращує якість продукції, } \\
\text { збільшує ії різномаїття; } \\
\text { - через виділення бізнес } \\
\text { одиниць забезпечує можливість } \\
\text { оптимізації витрат і } \\
\text { характеристик товару; } \\
\text { - дозволяє отримувати } \\
\text { синергійний ефект; } \\
\text { - знижує рівень ризику } \\
\text { виробничої діяльності; } \\
\text { - дозволяє опанувати нові ринки } \\
\text { збуту; } \\
\text { - отримуються додаткові } \\
\text { джерела надходжень, які } \\
\text { підвищують фінансову } \\
\text { стійкість підприємства; } \\
\text { - відбувається стабілізування } \\
\text { доходів; } \\
\text { - отримується можливість } \\
\text { раціонального використання } \\
\text { резервів }\end{array}$ & \begin{tabular}{|c|} 
Труднощі: \\
- складність управління; \\
- без виділення бізнес одиниць \\
підприємства втрачає переваги \\
спеціалізації і раціонального \\
використання наявних ресурсів; \\
- недостатність ресурсів для \\
повноцінного диверсифікування \\
діяльності; \\
- потреба в додаткових \\
інвестиціях; \\
- необхідність розширення \\
певних функціональних служб; \\
- ускладнення логістики; \\
- втрата часу на оновлення та \\
освоєння технологій \\
виробництва; \\
- ігнорування найважливіших \\
вимог стратегії конкуренції, \\
адже конкурують не цілі \\
диверсифіковані підпиємства, \\
а лише їх структурні одиниці
\end{tabular} & $\begin{array}{c}\text { Переваги: } \\
\text { - додаткові фінансові та } \\
\text { інвестиційні можливості; } \\
\text { - одержання синергійного ефекту; } \\
\text { - скорочення витрат, втрат, } \\
\text { раціоналізація їх складу та } \\
\text { структури; } \\
\text { - за рахунок узгодженості дій між } \\
\text { учасниками з’являється } \\
\text { можливість виключення } \\
\text { дублювання функцій; } \\
\text { - збільшення географічної } \\
\text { присутності на ринку; } \\
\text { - створення високого іміджу, } \\
\text { унікального бренду чи торгової } \\
\text { марки; } \\
\text { - консолідована реалізація певних } \\
\text { програм; } \\
\text { - зниження інформаційних } \\
\text { барєрів, підвищення ступеня } \\
\text { поінформованості; } \\
\text { - можливість залучення } \\
\text { додаткових ресурсів; } \\
\text { - дотримання соціальних } \\
\text { стандартів, норм; } \\
\text { - зростання ефективності } \\
\text { використання ресурсного } \\
\text { потенціалу }\end{array}$ & $\begin{array}{c}\text { Труднощі: } \\
\text { - можливість втрати права } \\
\text { власності на спільно-розроблені } \\
\text { продукти, інновації; } \\
\text { - підвищення складності } \\
\text { управління підприємством; } \\
\text { - складність зіставлення } \\
\text { отримуваних доходів і витрат } \\
\text { між учасниками; } \\
\text { - складність вибору надійних } \\
\text { стратегічних партнерів; } \\
\text { - втрата автономії, свободи дій, } \\
\text { контролю над бізнесом; } \\
\text { - послаблення мотивації } \\
\text { самостійного розвитку; } \\
\text { - можливість збереження } \\
\text { слабких стратегічних позицій } \\
\text { партнерів; } \\
\text { - складність створення синергії } \\
\text { різнорідними процесами різних } \\
\text { аспектів діяльності } \\
\text { підприємства; } \\
\text { - складність узгодження цілей } \\
\text { учасників, єдиних програм та } \\
\text { систем; } \\
\text { - ризики спільної діяльності } \\
\text { (втрата специфічних ресурсів, } \\
\text { іміджу, продуктової } \\
\text { винятковості тощо). }\end{array}$ \\
\hline
\end{tabular}

Рис. 3. Особливості застосування диверсифрікації та інтеграції сучасними підприємствами 
розвитку підприємств в умовах неотехнологічного відтворення.

Найвагомішими труднощами при реалізації кожної із зазначених фрорм розвитку є:

- відсутність достатньої кількості відповідних ресурсів і фрінансова нестабільність (при диверсиорікації);

- значний рівень залежності і складність задоволення особистих інтересів (при інтеграції).

Відповідно, ефективно відреагувати і вжити оптимально-результативних заходів зменшення впливу зміни чинників зовнішнього i внутрішнього середовища на діяльність підприємства в умовах неотехнологічного відтворення можливо за допомогою диверсифікаційно-інтеграційного розвитку, особливості застосування якого зображено на рис. 4.

Однак, ефективність процесу диверсифікаційно-інтеграційного розвитку вимагає ретельного аналізу наявного потенціалу і мож-

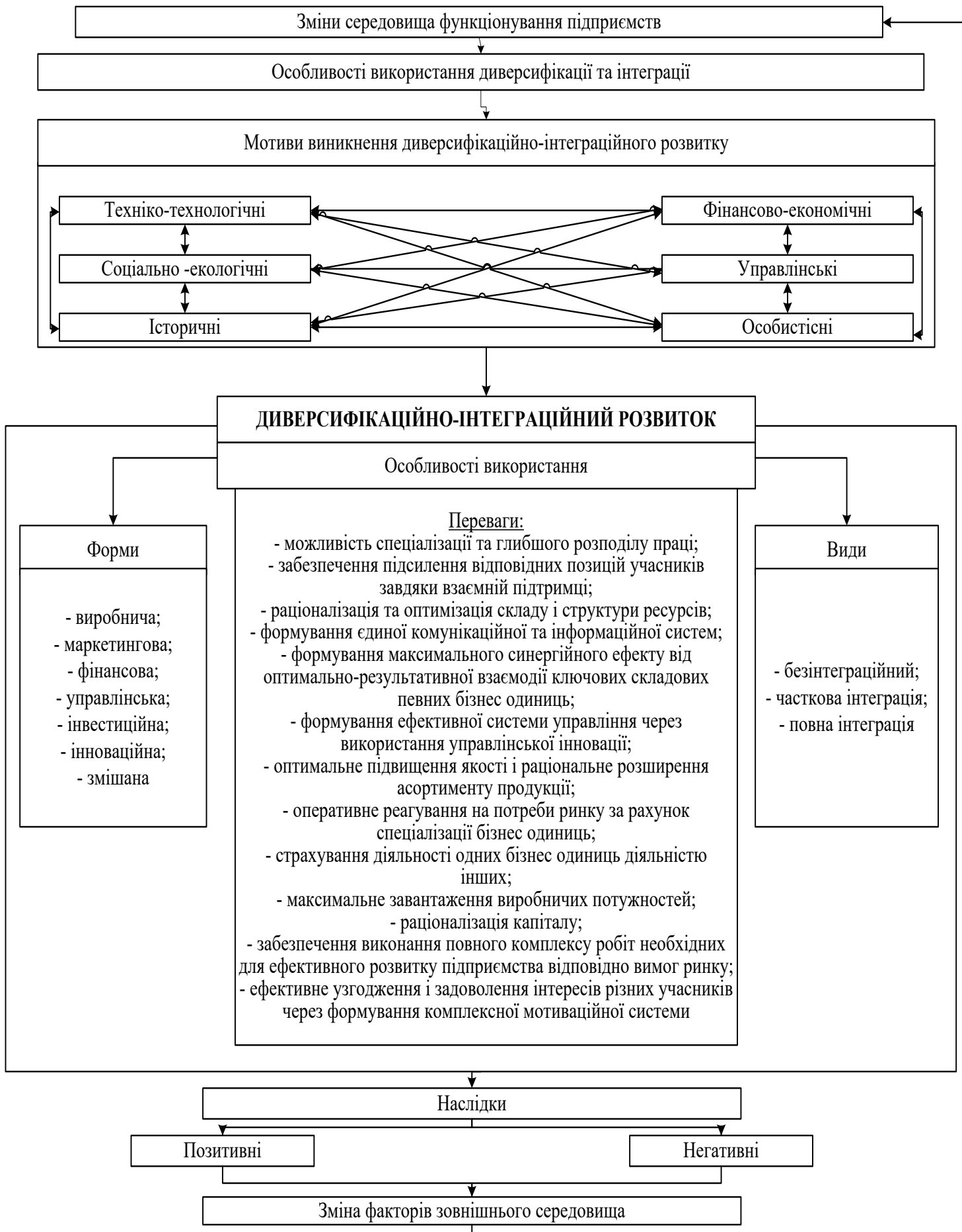

Рис. 4. Квінтесенція диверсифікаційно-інтеграційного розвитку 
ливостей його нарощення власними силами, співставлення отриманих даних із результатами взаємодії підприємства у цьому напрямку із сторонніми підприємствами (які тривалий час працюють у конкретному напрямку на ринку добре відомі серед споживачів і мають раціонально налагоджений виробничий цикл) і забезпечення ефективності їх взаємодії. Це можливо за рахунок ефективної системи управління, яка забезпечуватиме оптимальнорезультативну взаємодію різних структурних одиниць спрямовану на ефективне досягнення поставлених цілей стратегічного розвитку підприємства в динамічних умовах зовнішнього середовища.

Висновки. В статті окреслено фрактори впливу на розвиток сучасних підприємств в умовах неотехнологічного відтворення. Згруповано виділені чинники у дві групи: локальні; глобальні. Локальні у свою чергу розділено на ті, які впливають на підприємство на макро- i мікрорівні. Визначено заходи, які допоможуть уникнути негативного впливу і максимально врахувати позитивні аспекти виділених факторів впливу. Виділені заходи окремо згруповано у локальні та глобальні, що дозволило чіткіше окреслити вимоги до шляхів їх ефрективної реалізації.

Розглянуто можливість застосування диверсифікації та інтеграції підприємств для ефективної реалізації пропонованих заходів. Однак, труднощі окремого застосування диверсифікації та інтеграції унеможливлювали раціональне виконання певних заходів. Відповідно, у статті науково-теоретично обґрунтувано доцільність диверсифікаційно-інтеграційного розвитку, яке базується на квінтесенції диверсифікаційно-інтеграційного розвитку сорормованої за рахунок антагонізму особливостей диверсифрікації та інтеграції, що забезпечує гомеостаз розвитку підприємства в умовах неотехнологічного відтворення.

\section{Список використаних джерел:}

1. Люзе М.В., Окландер М.А. Перспективи диверсифрікації виробництва України в умовах інтеграційних процесів. Молодий вчений. 2014. № 5(1). С. 144-148.

2. Донець Л.І., Пруднікова Г.І Ризики диверсифікації господарської діяльності підприємства. Збірник наукових праць "Проблеми та перспективи розвитку підприємництва». 2012. Вип. 1. С. 16-20.

3. Кокова Э.Р. Диверсификация производства как фактор стимулирования интеграционных процессов в АПК. Научный журнал «Гуманитарные, социально-экономические и общественные науки». 2013. № 2. URL: http://www.online-science.ru/m/products/economi_sciense/gid400/pg0/

4. Скворцов І.Б., Цогла О.О. Обґрунтування та економічне оцінювання диверсифікації діяльності підприємств : монографрія. Львів : Ліга-Прес, 2012. 231 с.

5. Захарін С.В. Економічна диверсифікація як ефективний механізм забезпечення розвитку підприємства. Вісник КНУТД. 2012. № 1. С. 139-145.

6. Кузьмін О.Є., Передало Х.С., Дрималовська Х.В. Чинники впливу на диверсифікацію діяльності підприємств. Вісник Національного університету "Львівська політехніка»: "Менеджмент та підприємництво в Україні: етапи становлення і проблеми розвитку». 2013. № 769. С. 143-148.

7. Князєва О.А., Маслій Н.Д. Мотиви та цілі інтеграційних процесів на різних економічних рівнях. Науковий вісник Херсонського державного університету. Серія: економічні науки. 2015. № 2. C. 48-52.

8. Максимець О.В. Інтеграційні процеси у світовій лісовій, деревообробній та целюлозно-паперовій промисловості: еволюція, наслідки та можливості використання досвіду для України. Будуємо нову Україну. Збірник матеріалів міжнар. наук.-практ. конфб. Луцьк, 2014. С. 289-295.

9. Попик М.М. Вітчизняний і зарубіжний досвід інтеграційних процесів у промисловості. Науковий вісник Міжнародного гуманітарного університету. Серія : "Економіка і менеджмент». 2017. № 2. С. 12-15.

10. Скоробогатов М.М., Куцерубова О.І. Диверсифікація як один із шляхів підвищення ефективності діяльності підприємств у сучасних умовах. Економічний вісник Донбасу. 2011. № 3(25). С. $18-21$.

11. Корінько М.Д. Організаційно-економічний механізм диверсифікації діяльності суб'єктів господарювання. Актуальні проблеми економіки. 2008. № 6. С. 135-142.

\section{References:}

1. Luze M.V., Aucklander M.A. (2014). Perspektyvy dyversyfikatsii vyrobnytstva Ukrainy v umovakh intehratsiinykh protsesiv [Prospects for diversification of Ukrainian production in terms of integration processes]. Young Scientist, № 5(1), pp. 144-148.

2. Donets L.I., Prudnikova G.I. (2012). Ryzyky dyversyfikatsii hospodarskoi diialnosti pidpryiemstva [Risks of diversification of economic activity of the enterprise]. Collection of scientific works "Problems and prospects of business development", № 1, pp. 16-20. 
3. Kokova E.R. (2013). Diversifikatsiya proizvodstva kak faktor stimulirovaniya integratsionnykh protsessov $v$ APK [Diversification of production as a factor in stimulating integration processes in the agro-industrial complex]. Scientific journal "Humanities, socio-economic and social sciences", № 2. Available at: http://www.online-science.ru/m/products/economi_sciense/gid400/pg0/

4. Skvortsov I.B. (2012). Obgruntuvannia ta ekonomichne otsiniuvannia dyversyfikatsii diialnosti pidpryiemstv [Substantiation and economic assessment of diversification of enterprises]. Lviv: Liga-Press.

5. Zakharin S.V. (2012). Ekonomichna dyversyfikatsiia yak efektyvnyi mekhanizm zabezpechennia rozvytku pidpryiemstva [Economic diversification as an effective mechanism for ensuring the development of the enterprise]. Bulletin of KNUTD, № 1, pp. 139-145.

6. Kuzmin O.E., Peredalo H.S., Drymalovskaya Kh.V. (2013). Chynnyky vplyvu na dyversyfikatsiiu diialnosti pidpryiemstv [Factors influencing the diversification of enterprises]. Bulletin of the National University "Lviv Polytechnic": "Management and Entrepreneurship in Ukraine: Stages of Formation and Problems of Development", № 769, pp. 143-148.

7. Knyazeva, O.A. \& Masliy, N.D. (2015). Motyvy ta tsili intehratsiinykh protsesiv na riznykh ekonomichnykh rivniakh [Motives and goals of integration processes at different economic levels]. Scientific Bulletin of Kherson State University. Series: Economic Sciences, № 10(2), pp. 48-52.

8. Maximets, O.V. (2014). Intehratsiini protsesy u svitovii lisovii, derevoobrobnii ta tseliulozno-paperovii promyslovosti: evoliutsiia, naslidky ta mozhlyvosti vykorystannia dosvidu dlia Ukrainy [Integration processes in the world forest, woodworking and pulp and paper industries: evolution, consequences and possibilities of using the experience for Ukraine]. We are building a new Ukraine. Collection of materials international. scientific-practical conf. Lutsk.

9. Popik, M.M. (2017). Vitchyznianyi i zarubizhnyi dosvid intehratsiinykh protsesiv u promyslovosti [Domestic and foreign experience of integration processes in industry]. Scientific Bulletin of the International Humanities University. Series: "Economics and Management", № 25(2), pp. 12-15.

10. Skorobogatov M.M., Kutserubova O.I. (2011). Dyversyfikatsiia yak odyn iz shliakhiv pidvyshchennia efektyvnosti diialnosti pidpryiemstv u suchasnykh umovakh [Diversification as one of the ways to increase the efficiency of enterprises in modern conditions]. Economic Bulletin of Donbass, № 3(25), pp. 18-21.

11. Korinko M.D. (2008). Orhanizatsiino-ekonomichnyi mekhanizm dyversyfikatsii diialnosti subiektiv hospodariuvannia [Organizational and economic mechanism of diversification of business entities]. Actual problems of economy, № 6, pp. 135-142. 